\title{
Eighty Something: Banking for the older old
}

\author{
John Vines Mark Blythe \\ School of Design \\ Northumbria University \\ Newcastle upon Tyne, NE1 8ST \\ john.vines@northumbria.ac.uk \\ mark.blythe@northumbria.ac.uk
}

\author{
Paul Dunphy \\ Culture Lab \\ Newcastle University \\ Newcastle upon Tyne, NE1 7RU \\ p.m.dunphy@newcastle.ac.uk
}

\author{
Andrew Monk \\ Department of Psychology \\ University of York \\ York, YO10 5DD \\ a.monk@psych.york.ac.uk
}

\begin{abstract}
An eighty year old today is expected on average to live well beyond the year 2020 . However the needs of the older old are seldom considered in relation to current and future banking services. This paper documents a qualitative study investigating the meaning of money to a group of eighty somethings (people aged over 80). Participants were asked to tell their financial life stories. This focus on biography allowed them to relate rich narratives that indicated enduring values and concerns. Interviews with twelve participants as well as carers and financial experts were transcribed and analysed using a grounded theory technique. The key themes that emerged from these data were: materiality, control, locality and transferability. We discuss the implications of this study in reference to the next stage of design and policy focused research that aims to benefit the broader community.
\end{abstract}

Older old. Experience-centred banking. Usable security. Grounded theory.

\section{INTRODUCTION}

In 1921 the life expectancy for men was 61 and for women 68 (Collerton et al. 2009). The twelve participants in this study were over eighty and have already lived longer than expected. Today an eighty year old in the UK will live, on average, for another eleven years (Dini and Goldring 2008). Indeed eighty to eighty-five year olds make up the fastest growing section of the population in the world (United Nations 2002). This demographic are commonly referred to as the "older old" (Collerton et al. 2009), but this paper will use a more descriptive and neutral term - eighty somethings. In 2007, the United Kingdom's (UK) Treasury put into place a financial inclusion strategy intended to ensure that 'everyone has the opportunity to access the financial service products needed to participate fully in modern-day society' (HM Treasury 2007 p.5). It acknowledged that the rising numbers of older people, particularly the oldest old, in the UK was a central problem to be tackled by the new strategy. We argue that there is still a significant gap between the services provided by the UK's banking industry and the everyday banking practices of the older old.

The vast majority of current banking products and services are not designed to be inclusive of minority groups (Financial Services Authority 2009). A report published by Age UK (Wells 2008) found that banks were poor at providing information on the topics of interest to older people and that there is little to no provision for people who have to rely on others to carry out financial transactions for them. It has also been observed that many older people are nervous of their personal security when using ATMs, phone banking and internet banking (Ibid). The Age UK report noted that community settings and face-to-face services at the local Post Office are highly valued by this age group and this study confirms many of these observations. Clearly, there is still a significant gap between the services provided by the UK's banking industry and the everyday banking practices of some eighty somethings.

\section{USABLE SECURITY}

PINs, passwords and a general unfamiliarity with the security concepts underlying contemporary technologies are fundamental reasons for the exclusion of the older old from banking (Financial Services Authority 2009; Wells 2008).

The field of user-centred security has highlighted how mechanisms for providing security and privacy have continuously been designed with usability and accessibility scarcely considered (Adams and Sasse 1999). There is often a significant distance between the theoretical security of a system and 
the practical security of groups of people working or living alongside one-another (Dourish et al. 2004). To take one example, people will often need to share user names, PINs, and passwords. Singh et al. (2007) studied the banking and security practices of married and de-facto couples, remote indigenous populations and people with disabilities. In all these groups it was common to share user names, PINs, and passwords, often for very good practical reasons. To take an extreme example from their study, communities on the remote Torres Straight islands have to send someone on an overnight journey, via a plane, to a nearby island to complete financial transactions on behalf of several people. This person will complete a large number of transactions using the personal details shared with them by others. Even in developed countries, the assumption that everyone has access to a nearby ATM with which they can complete personal banking transactions for themselves is not justified. Workarounds for sharing sensitive information develop between security protocols and longestablished community practices (Singh et al. 2007).

This study of UK eighty somethings suggest that such workarounds are also necessary for the older old even where they live in the heart of a city with an ATM on every corner. For some, leaving home at all can be difficult and they must rely on others to perform routine banking activities. Beyond this, the study highlights the profound distance between a lifetime's experience of banking for an eighty something and contemporary technologically mediated banking and finance.

\section{THE STUDY}

The study took place over a two month period in the north of England. The participants were twelve people over eighty years of age. Ten of the participants were living independently in their own homes, one was in a warden assisted flat and one was a resident in a care home. Participants were recruited from a "Darby and Joan" social club that ran from a local church. Participants were also recruited from this church's congregation. Written informed consent was obtained from each of the participants. Interviews lasted between two and three hours and participants were paid for each interview, though many immediately donated the money to charity.

The interview consisted of a "financial biography". Participants were asked to tell their life story and warned that the interviewer would be interrupting to ask about finances. Typically the interview began with childhood memories of the way their parents organised their finances and whether or not they received any pocket money, birthday and
Christmas presents. They would then move on to leaving school (for most of these participants at the age of 14), what their first job/wage was and what they did with their earnings. The interviews continued to discuss leaving home, marriage, mortgages, children, career and retirement. Any time of upheaval (career change, moving home, major purchase, retirement) is usually accompanied by a re-organisation of finances, so where money was not mentioned by the participants the interviewer would ask a direct question. Participants enjoyed relating their life story and relaxed enough to share quite intimate financial details with the interviewer.

These interviews with the eighty somethings were supplemented by interviews with care professionals in organisations such as Age UK and experts from the financial sector. These included in depth interviews with a finance officer at Age UK, two care home managers, a vicar who worked with many of the elderly participants, two specialist welfare benefit advisors, the head of research in a large banking organisation and a financial anthropologist and co-founder of Zopa - a new banking service.

The interview transcripts were analysed through a grounded theory methodology (Glaser and Strauss 1967; Charmaz 2006). Data was summarised with open-ended codes. These initial codes were then grouped together into themes. Connections between these themes were the basis of the grounded theory where theory is understood as a broad and reflective description rather than predictive model (Charmaz 2006). Excerpts and quotations were selected from the data to illustrate the theory. All participant names have been changed. Qualitative studies of this kind do not seek to generalise findings to a wider population but rather provide rich accounts of individual cases. The following sections discuss the four themes emerging from the analysis; materiality, control, locality, and transferability.

\subsection{Materiality: florins and shillings}

The participants grew up in a period where financial transactions were cash-based. Rent money was collected door-to-door and everyday perishables such as milk were paid for on the doorstep. Doreen, for example, recollects: 'Oh yes, it was on them coins, I mean we used to wait for't gas man coming to empty your meter, and then you got so much money back and so, it were in parts, I mean he took some but there was so much money back, so that was a bonus.' All of the interviewees handled coins (florins, shillings and bobs) from an early age. For many, such as Hetty, the use of cash endures into late life: "If am paying the council tax or the gas bill or whatever, I use cash. I don't know 
why I do that, but I do." The preference for cash amongst the older old is well documented (Wells 2008). The reasons for this are partly biographical but only partly.

Jean described how she ensured she had enough cash to cover her for a given period of time. "I do have a certain amount of cash which I like by me ... I go to the bank and I get so much money out of the bank. I make sure that I have so much money in." Like many of the participants, Jean collects this cash and hides it around her home. "I have a spot here where I save up. I'll always have so much for the housekeeping." These participants kept their cash in close proximity to themselves and their home as a visible indication of how much money they had spent. The notes and coins then were a tangible measure of how much was allocated for a given period and how much was left.

Thora describes her monthly trip to the bank: "I take my book in, have it made up for the month, then I look to make sure everything has gone in, and then I draw the money out that I want." Thora withdraws her monthly amount of money all in one transaction and then carries this through town to her home. "She always puts it in an envelope for me and I tuck it right in the bottom of my bag until I get home." Thora does not feel nervous about carrying large amounts of cash, it is discretely hidden in a basket on her mobility scooter.

Similar habits of saving cash and storing it around the home were also reported in the interviews with care home mangers. Lynn noted that residents often got cash to keep by them that would sometimes mount up to large amounts: "I opened this drawer and it was stuffed full of tenners. ... There was about $£ 500$ which obviously I handed over to the family. ... Apparently she always used to like to get new notes when it was her grandchildren's birthdays. Still getting the money but not actually giving it to the grandchildren, it was just getting stuffed in this drawer." Lynn describes how this resident continued the practice of saving and storing away bank notes without spending them, leading to a significant security risk.

Annie, another care home manager, recalls a home visit where she was assessing the needs of a new resident. Banknotes were "in all sorts of different places, a shoe box here and something there. They clearly think that this is perfectly safe." Recalling another home visit experience, she described rooms full of unopened pension envelopes: "She'd get her pension, and of course she had enough pension left from the week before, she just left it in an envelope." The envelopes full of money built up over a period of years and carers including Annie discovered "thousands of pounds" in cash secreted around the house. Annie and a council social worker had the uncomfortable responsibility of receipting the cash and taking it to the resident's bank.

Keeping large amounts of cash around the house was often something that the participants parents and extended family had always done. Thora's Grandmother was a moneylender in the East End of London whose ruthless loan sharking shocked members of her own family: "she used to keep all her money .... in a big box with a lock on. ... A bomb exploded one night and when it came to my grandmother looking for her box, it had been taken and she'd lost all her money. I can remember my Mum saying Jesus, Mary and Joseph, it serves her right!" Thora does not keep all of her money in her home like her grandmother did, but her monthly visits to the bank mean up to $£ 400$ in cash is often kept in her house.

Reports of the homes of older people getting targeted for thefts are common and on occasion people have lost their life's savings (Bell 2010). Many eighty somethings are aware of such threats, even from care workers who come in to help them. Lynn refers to the "money traps" that some residents would leave: "20 pences put in key places and if you were cleaning you had to put them back in the same place otherwise she thought they'd been stolen." The coins are more than a material token of monetary value; they act as both a deterrent and tool for tracking the security of one's belongings.

Throughout the interviews the material qualities of coins and notes were emphasised. Betty contrasts her way of managing her finances with those times when her Granddaughter does it on her behalf. "My granddaughter is very modern ... she is saving up for me some place, so I gave her so much money at the weekend. Sometimes she'll come back and she says, well it went in, I put it in big envelope and its come back, it's in. I says, I can't do with that. I like spot on, I like to see it." In this case her Granddaughter's account of a deposit being made was not good enough. Betty wanted material proof that the bank has received the money. In her own words, she likes "to see it". This sensorial attachment to the material surrounding personal banking is repeated throughout the interviews; "I'll either do it over the counter, because I'm handling it myself, I know what l'm doing with it'. Here, Doreen makes explicit the intimate visual and tactile connection she has with her finances, and her knowing that a transaction has been successful.

Attacks on elderly people are well documented in the British press. Incidents of purse snatching are reported as "granny bashing" and there is an understandable emphasis on the cowardice of 
attacking a vulnerable person. But it is not solely vulnerability that makes older people targets for thieves. Snatching the purse or wallet of any of these participants would have been far more profitable than mugging the researcher interviewing them. Statistically, the fear of crime is far greater amongst elderly people than the actual likelihood of it (Help the Aged 2006). However, whilst aware of potential risks, these eighty somethings were not worried about crime. In some cases, even distressing experiences of crime were not enough to change their attitudes. Jean for instance, described being mugged: "I had done all my shopping one Saturday morning, right from behind, just grabbed my bag and away. All my keys, my money and the lot went." Despite this experience, Jean continues making her trips into town with a renewed caution. She declares, "I am watchful. I keep looking back, this taught me to keep looking like this." Another participant, Ruby, had recently been the victim of a walk by burglary; she had left her door open and a thief had snatched her purse from a key table. She had lost around three hundred pounds in cash. Ruby also kept her debit card in a zipped compartment of her purse and along with a piece of paper with the pin number on which the thief used to withdraw another three hundred pounds.

Although the security risks are not lost on the participants themselves there are also benefits. The cash in the envelope is either there or it is not, the money for the day, or the week, or the month is spent or it is not. Indicators such as numbers on an ATM screen are not adequate replacements for material tokens like coins and notes. The reliance on cash then is not simply an accident of personal history and biography, it is not simply what they are used. To use Gibson's (1986) terminology, there are particular affordances that are valued. For these eighty somethings the crucial affordances are those of countability, hideability, portability and transferability.

\subsection{Control: record keeping and thrift}

All of these participants had kept a careful check on their finances throughout their lives. Jean still compares monthly bank statements with her own records: "I write it on a sheet. I have my bank statement and if the bank say I have $£ 2,300$ in and I think right, next month that's to come out. I check to make sure that the bank has paid all that out. Sometimes when I am getting groceries, in winter time I get a lot to last me three weeks. I pay with my card and I check that and I think that's to come out."

Although the eighty somethings are idiosyncratic in how they keep records, efforts to maintain control persist. Thora explains: "I write out me carers, me gas, me light, me phone and hair, feet - chiropodist, water, television, St Leonard's Hospice which I support, church - how much I donate each week and then I give a bit extra at Christmas, that all goes down." Michael keeps all of his records: "I have a filing cabinet, I file it all." Some of the eighty somethings kept small notebooks detailing every transaction (figure 1). Most of the participants had quite rigorous and time consuming routines that helped them keep track of incomings, outgoings and multiple current and savings accounts. This lifetime of practice was disrupted for one participant who had recently lost most of his sight. Bank statements were now unreadable, he did not trust his carers enough to read them out, and consequently had little knowledge of how much money remained in his accounts.

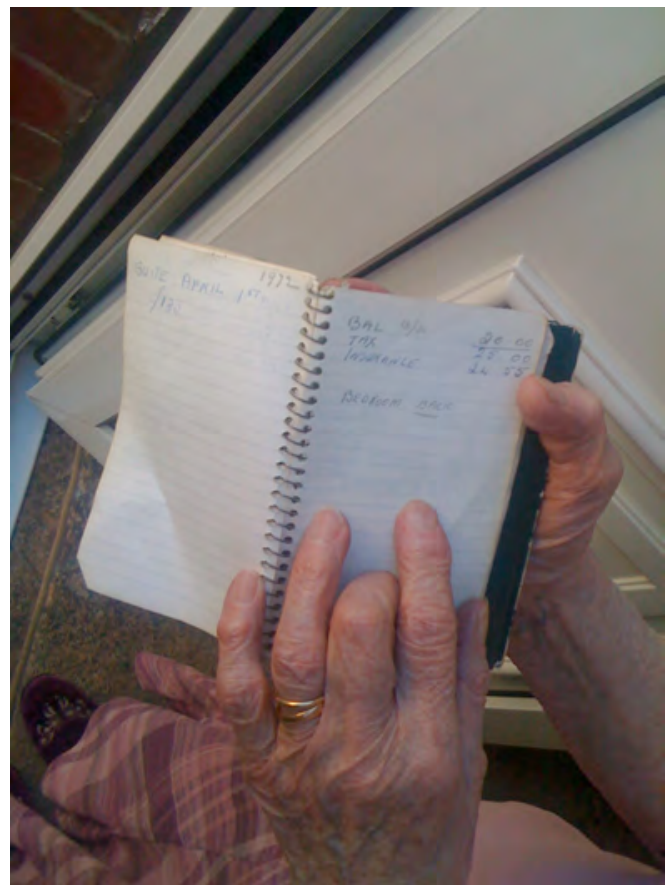

Figure 1: Finance Notebook

Although there is a ritual aspect to such behaviour it can uncover mistakes, as Jean describes in detail. "One time, I got the bank statement, I'm going back two years, and somebody had put $£ 80$ in. I thought where's this come from? ... I said I want to know about this, it's not my money. She took it away, and she came back and said this has slipped in, it's the computer evidently. It's going to be paid back. I said - take it out now so I know where I am then!" This is not to say that the participants do not realise their own records are at fault on occasions. Jean recollected how "once l'd missed something, I hadn't added my superann [pension] on. I thought I shouldn't have all this money, because it's a good superann, it's £200 a month roughly. I thought I've got this money over, but I went through it meticulously and I thought that's it." Whether it is the individual at fault or the banking institution, there is a clear resolve to regain 
control. "I says I'll have another note on that as soon you can. So within a few days they sent me another statement. ... I know what goes in and what comes out." Jean accepted her error but the issue was not resolved until she received material confirmation, allowing her meticulous records to be updated.

Unlike all of the other participants Jim was happy to use a computer and used it to manage his numerous savings accounts and investments, often searching the Internet for the best interest rates and deals. Recollecting his earlier experiences of investing during the 1980s, he discusses how he kept records of where his money was every week. "If I'd had a computer at that time I would have put it on there and let it do the work for me." Jim, however, is exceptional among these eighty somethings. For most, the desire to keep tight control of their finances meant resisting digital technology. When asked whether they used phone and internet banking, replies were for the most part; "no, no I don't want to"; "I don't get a computer, but I couldn't cope with the mobile phone"; "I can't work that [the phone] let alone a computer." Care home manger Lynn remarks on an 89 year old lady she regularly visits: "She ran a business, [but] she absolutely will not go onto paying bills by direct debit, even though she has got an appropriate bank account". Reflecting on the surprising reluctance of the retired businesswoman to use automated services, Lynn observes that "she feels that she is in control". For many of these eighty somethings, it is important to know that everything is, literally, in hand.

The necessity to keep material control of one's finances also emerges as an absolute aversion to debt. Certain types of debt are acceptedmortgages and car finance deals, for example-but there is a profound discomfort with the use of credit cards and bank loans. "No, l've never had a credit card. I've never wanted to get myself in debt, I never have done." The strongest feelings about debt and credit were often expressed in relation to the differences between them, their children and their grandchildren. "These youngsters are more easily in debt to what we were. ... They don't seem to bother do they? I'd be worried to death if I owed any money, I would. ... Spend and waste! They spend and spend." The shock at the way younger people spend money may be a result of limited personal experiences of debt, which are mostly recollected as hugely negative. Doreen recalls paying off her mortgage: "It was a struggle with our wages then, we didn't have money, you couldn't go and buy all sorts then. We could just make the mortgage money." The desire to avoid debt often meant a preference for the hardships of incrementally saving instead. "Because we didn't think that, say you are buying an arm chair and it was $£ 50$ and you got it on the never, never you've paid £60 for it, you'd pay interest and it would work out nearly $£ 10$ more. So we didn't want to do that, we wanted to persevere and get them as we could afford them." Huge satisfaction is taken from being able to stay away from debt: "I don't owe them anything and they don't owe me anything."

The thrifty attitude of the participants is noted by Craig, the local vicar, in the problems he has getting his Church committee (mostly made up of older parishioners) to agree to borrowing significant amounts of money to invest in the building. "The attitude [is]... we managed yesterday without this, therefore we can manage tomorrow without this, therefore we won't spend. Which can make it very difficult to look at the way that we can invest the physical resources that we have as a community, the way that we can invest in trying to promote things within the church, or develop quality." An implicit ethic emerges where the spending of borrowed money is inherently wrong. There is an element of self-control that perhaps echoes the kinds of hardships the participants experienced during youth and war year rationing. Craig reflects on how his generation's financial habits contrast with his older parishioners: "We are not kind of emotionally predisposed to the notion of waiting and saving for something." For these eighty somethings, however, waiting and saving is embedded in their way of life.

Control over finances and control over themselves appears as a central theme to the lifetime of financial experiences for the participants in this study. Control is intimately connected with the previous theme of materiality, and also surfaces in the following theme of locality.

\subsection{Locality: familiar places and faces}

Most of the participants in the study had lived in the same street for most of their lives. It was not unusual for people to have lived in the same area their entire lives, going to school and working in the neighbourhood. For many of the eighty somethings the local roads, shops, people, banks and Post Offices are intimate networks of financial activity.

Doreen, for example, had lived on the same road all her life, went to school just streets away, worked in the local chocolate factory and bought her house from a gentlemen who ran the local corner shop. She recalls the early experiences of having to make the repayments on her house: "I thought how are we gonna get $£ 800$. I thought oh dear, can we get, and we wanted £200 deposit which I mean we managed to do that ... I paid £4 a month back." Doreen used the local building society to borrow the money. She did not shop around: "you was just glad that you'd got somebody that was gonna do it 
for you." Every month Doreen would go in person to make the payments, which were recorded in a bank book, and eventually the house was paid off. Later Doreen sold this house and moved to another one very close by. No bank was involved and she collected monthly payments herself using a notebook she bought from Smiths over a period of eight years until the debt was paid. Here, the material interaction with cash and the record keeping it produced were intimately tied to the locality of the places and people she interacted with.

The friendships and social networks established within a neighbourhood were harnessed by some in periods of financial need. The hardships of the war and post-war periods appear to have resulted in a heightened sensitivity to the benefits of bringing together a community's financial recourses. Thora recalls her father operating a "pound club". "We had so many neighbours, all good friends... They used to pay a pound a week in, I think there was 20 of us altogether. You took it in turns, the first people could borrow that money. Then they paid it back and it went round in the circle so everybody got a turn of having this big bit of money. Then we paid a shilling a week interest on that. So at the end of the year, when my father did the books, whatever interest he had collected in, we all got a bit back as a bonus." What Thora describes is an early form of social lending, where a community shared the burden of individual households making large purchases and, eventually, everyone got a little bit of money back at the end. These financial activities were not only necessary as a result of the prevailing political and economic conditions but were also amplified by the locality and proximity within which these people lived their lives.

Rather than let automated and electronic payment systems alter their activities, a number of the participants' described a preference to walk to shops, banks and Post Offices and pay in person. "It's convenient, because living in town, all l've got to do is walk into town which is not very far and just pay it." Hilda commented: "I like to go in the bank. I try and keep going as much as I can. When I can't go, I can't go." The problem for Hilda, however, is that resolving problems when not physically in the bank is difficult. Therefore, going to the bank in person is more effective than using electronic alternatives to accessing customer services. "When I go to the bank I get said what I want to say. They are very good, you can talk to the cashier." Telephone banking was not countenanced as an alternative for Hilda, who exclaimed, "I tell you I'm old fashioned!"

Whilst Thora is concerned about the stories she hears about crime, she finds comfort in familiar routes, places and faces. "I go the route where I know and people know me. I know quite a lot of people who call out - good morning." A sense of community and belonging comes across in recollections of the town centre of old and the elements that remain. There is a sense of security in seeing the people she knows.

Many of the participants had used the Post Office, rather than a bank or building society, as their primary access to money. The recent death of the gentleman running the local Post Office had disrupted routines cherished by this group. "I miss this post office here, l've got to go down to the bank, l've to pay $£ 4$ each time I go down by taxi." These trips are difficult to make. "Now we have to go into Colliergate for our money, but l've been finding it pretty hard to go. So they're just transferring over to the bank to the Nationwide." Adjusting from local Post Office to commercial bank, however, is not a simple transition. There is a prevailing attitude that the bank is less personable than the Post Office is. In situations where an individual finds an element of belonging, it is difficult to maintain. "One of the girls works at the Colliergate one, but it's so busy in there you only have chance to say hello to her, you don't have a chance to have a little natter to them." The Post Office is more than just a service provider for many of these eighty somethings; it is also a centre of social interaction, formed around everyday banter, gossip and reflections on local life. Craig the Vicar reflects on the effect this has on his older parishioners. The Post Office is "important at all kinds of levels ... many elderly people will look for a home within striking distance of a post office. So when their post office disappears that throws into disarray their plans as to where would be a good place for them as elderly people to live." These comments correspond with recent figures indicating that the older a person is, the more likely they are to use the Post Office (Department of Business 2010), whilst reports in the media on closures often dwell upon the problems this will cause elderly customers (BBC 2010).

The locality within which financial interactions occur are of utmost importance to the participants in this study. Not only is this related to the material and geographical locale but also the social networks that are subtly entwined within the activity of going to the Post Office or the bank. The manner in which cash is embedded within such social networks emerges particularly strongly in the ways in which the eighty somethings deal with other people's finances. This is described in the final theme of transferability. 


\subsection{Transferability: spending through, with and via others}

The participants had often had intimate dealings with other people's finances and, in later life, had others deal with theirs. As noted in the previous section, times of financial hardship brought neighbours together to temporarily share their financial resources in order to benefit one-another. From an early age, spending other people's money is a recurrent theme for the eighty somethings. In youth this often came in the form of popping down to the local shop to buy everyday items for elder members of the family. "Mum'd give you money to go for the bread across the road." Similarly "Then there was my mother's mother. I used to go to the fish shop for her. She used to give me a penny and $I$ used to get two farthing bloaters, a farthing of mashed potato." Johnny recalls that if he was lucky he could keep the change: "the other farthing I could have for going, so that penny went a long, long way." After starting work the sharing of money moved from receiving to giving. Earning money meant supporting the rest of the family. "Mum needed it for the house and it was like paying for me board and lodge." The consequence of giving early earnings away often meant very little was left over to spend on luxuries. "You'd nothing left had you? You gave it to mother and she gave you 5 shillings or something like that." Such personal poverty, however, was not necessarily seen as enforced by the family. As George points out, "it just seemed natural to give it to me mother."

It might be the case that the experience of such poverty, hardships and necessity to share money at an early age has heightened the participant's sensitivity to giving away money in later life. Many of those interviewed belonged to charitable organisations, to whom money was given at regular intervals. The Vicar highlighted that "they will very rarely refuse to give anything, there is a kind of a strong sense of duty that if the collection is being made for something, then they ought to contribute." Craig, interprets this sense of duty as related to the hardships lived through at a younger age-war, rationing, poverty. From his perspective such experiences may have helped establish a sense that good must be done for the benefit of the wider community.

The sharing of money was important for all of the participants. One ninety year old remarked of his money "I just want to get rid of it". His wife had died recently and he did not expect to live much longer, he was keen to make sure that the people he wanted to have his money, family and particular charities, got the money and not the state. But redistributing money was not just in preparation for death. They had shared their finances throughout their lives with husbands and wives, with elderly parents and grandparents. Sandra presents one such case, where she and her Brother stayed in the family home to look after their ailing Mother. After her Mother passed away, they stayed in the family home and costs were always shared between the family: "we all just clubbed together and paid so much." Many situations arose over the lifetimes of these eighty somethings where money had been entrusted to them by others, or they had shared their own finances with those who they cared about. These behaviours endure into older age. As Thora states: "The bills come in, I've got my cash, I give it to my carer and she goes and pays." Situations arise where money is handed over to care workers and family members to pay bills or buy everyday items.

As Singh et al. (2007) observe the transition to an economy dominated by electronic transactions performed through passwords and PIN numbers does not preclude long held practices of shairng. "My granddaughter, she knows my number and she can go and use my card" and "if I want anything out of the wall, Nigel will get me 100 out if I need it." Situations such as these bring to the fore significant questions about personal financial security, for both the sharer and carer, as described by care home manger Lynn: "I have actually had them stand next to me in a shop and tell me their PIN number. Why couldn't we have sorted this before we went out, why didn't you tell me it. l've just got to remember this 4 digit number for today and then I can forget about it for the rest of my life. That is a huge trust issue." For this carer, however, there is a sense that without such help the residents will become disconnected from financial transactions.

PINs and passwords have often been cited as a barrier for older people accessing their finances. Even Jim, one of the more technically informed participants, acknowledged his difficulty with PINs and passwords. Upon being questioned about writing these down, he observed: "I ought not to but I do." It is not just that PINs are barriers for accessibility, however. As with Singh et al.'s study there is here a very wide gap between theoretical banking procedures and actual procedures. These were illustrated most vividly when Lynn described accompanying an elderly person to the bank who was unable to prove her identity: her signature was nothing like those on record, her passport and other ID were years out of date and she could not remember any of the personal information that the bank asked for. Here Lynn recounts trying to prompt the resident for some documentation she might have: "I'm trying to work through my head what else she might use that was a monthly bill. "What about your telephone bill, don't you do that?" [quoting the resident] "I think you're right."' Lynn's prompts eventually aided the lady in gaining access to her account. This is done through an explicit 
negotiation of the theoretically secure system where information such as this should not be shared.

\section{DIRECTIONS FOR DESIGN AND POLICY}

This study has discussed some of the strategies used by this group of eighty somethings to maintain the financial activities they have practiced for a lifetime. Interactions with material currency emerge as key to an enduring sensitivity to the tactile, visual, countable, hideable, portable and transferable qualities of money. These qualities also manifest in the practices many of the eighty somethings engage in to record, track and precisely control their financial transactions. These matters of materiality are extended into the area they inhabit and the locality within which their financial interactions take place. Nearby Post Offices, neighbourhood streets, doorsteps and local shops all act as places that provide tactile and visual presence to their financial interactions. The social dimension of finances for these eighty somethings is strengthened by their generosity and insistence on the transferability of money. Unlike PINs and debit cards, cash can be handed from one person to another and as dependence on carers increases this becomes ever more important.

Previous studies have observed that people switch technologies and media based upon the level of security they perceive it to afford. For example, young people engaging in instant messaging conversations would take it to a phone call when private issues are raised (Grinter and Palen 2002). Similarly, for the eighty somethings the medium of cash and the network of objects, institutions and persons encompassing their life-long experiences of money afford a level of immediate security and trust that becomes opaque in electronic transactions. This group of eighty somethings were contented with collecting cash, walking down the street with cash, and storing cash in places throughout their homes. They are, more often than not, very aware of the dangers of these practicesbut they continue nonetheless. The attachment to the material of their finances-coins, notes, cheques, slips, receipts and passbooks-all support their ongoing achievement in controlling their incomings and outgoings. These are practices to be harnessed by designers and policy makers, and not to be dismissed.

Niall Ferguson reminds us in The Ascent of Money (2008) that coins and banknotes are as much a form of debt as credit cards. The earliest archaeological record of an artefact recognisable as money is a clay tablet from the second millennium BC. The inscription promises to pay the bearer of the tablet 330 measures of barley (Ferguson 2008). What is interesting here is that it promises to pay the bearer and not the person: it is transferable. The quality which makes it stealable is also that which makes it flexible. In its earliest form money was a form of promise. In theory it still is, and notes from the bank of England still say "I promise to pay the bearer on demand the sum of" five, ten, twenty or fifty pounds. Before the link to the gold standard was abandoned this meant in principle, though not for many years in practice, that the note could be exchanged for gold. "Public trust in the pound is now maintained by the operation of monetary policy, the objective of which is price stability" (Bank of England 2011). Trust and belief then are now more than ever central to the valuation of money. It is this same trust that enabled one of the eighty somethings to sell her house based upon the records contained in a single book.

In the age of globalisation the banks allegiance is not to any geographical area nor even any nation state, but to its shareholders. Now more than ever there is a need for alternatives. In Liquid Modernity Bauman (2000) points out that increasingly all forms of social relationship and identity are liquid: employment, marriage, friendship, where we live, what we call home. New forms of banking like Zopa (2005), and at least in its early conceptions, microfinance, aim to re-establish links between borrower and lender (Davis 2010, pers com). It was this entanglement between borrowing and lending that had allowed Thora's father to persuade his neighbours to pool their financial resources in order to benefit each individual member of the "pound club".

Cash is secure for the eighty somethings as it provides an immediate material presence that is not afforded by electronic finances. It can be hidden from prying eyes in bags, boxes, drawers and mattresses. Cash can be directly handled, and seen to be handled by others. Trust is engendered by being able to see transactions taking place, by seeing who it is you are entrusting with your finances, and by communicating in person what it is you want them to do with your money. The paradigmatic change to electronic banking, however, has for the most part ignored the power of these material and social qualities.

At this stage, it is possible to highlight two fundamental implications of this initial study for future research-the first centres on design, the second on policy.

Firstly, designers could give greater agency to the older old by developing interactions with electronic banking that take into account the strong relationships the older old have with material 
finances. Alongside a consideration of materiality should come a greater sensitivity to physical and social contexts and locales. Research on tangible and physical computing offers one potential route for designers to explore. Emerging technologies such as smart paper could provide a meeting point between the metaphors and experiences of the older old with the requirements of the electronic banking industry. To make a chindogu or "unuseless" illustration (Kawakami 1997) perhaps the image on a smart banknote could reduce as each pound and penny is spent (figure 2). It should be stressed that this is not a proposed solution but an "unuseless" concept to indicate the way that the issues uncovered in the study might connect to design.

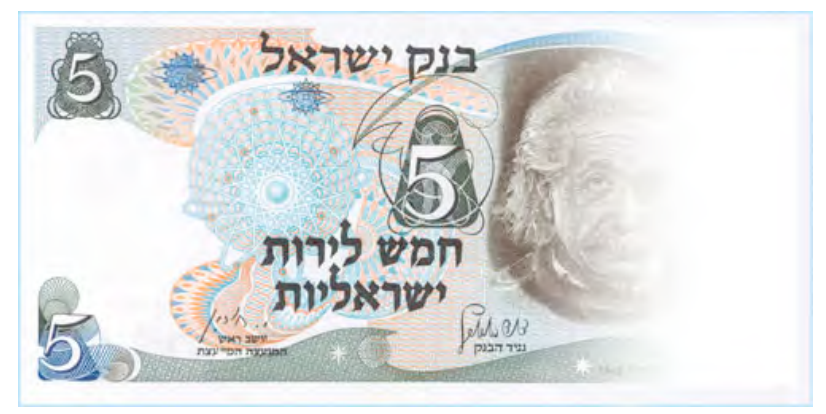

Figure 2: A smart banknote that fades proportionally as its value is used.

Secondly, the banking industry must accept the fundamental social phenomena of older people in inter-dependent networks where the model of a contract with a single individual is inappropriate. Banking policy might allow for the temporary transferability of financial responsibility. For example, one way of reducing the problems of PIN sharing could be to utilise multiple PINs, with authorisations of various levels of access for different PINs. Current banking terms and conditions, however, prevent this (see Barclays Bank 2011). At this time, current and saving accounts either grant full access for multiple account holders or those with power of attorney, or no access at all. As observed in this study, however, the social practices of some eighty somethigns require a greater level of flexibility in terms of the transferral of money from one to another, and many of these financial transactions do not conform to an all or nothing scale. Rather than considering this group of customers as requiring particular financial education, banks and financial institutions could learn from studying their experience and practices in order to provide better services for everyone.

\section{CONCLUSION}

Despite attempts to make banking services and products more inclusive there is still a significant gap between banking infrastructure and the practices of the older old. The eighty somethings participating in our study find value in their financial transactions beyond those of profit or loss. Through describing their financial biographies, they have highlighted the intimacy of their interactions with the materials of their finances. Trust emerges in complex social networks through the tactile and visual qualities of their financial interactions, and this trust engenders a sense of transferability and sharing with others in their community. This paper has argued that it would benefit designers of interactive systems and policy makers within the financial sector to harness these practices. Rather than considering them defects to be ignored or educated away, the sensitivities of the eighty somethings must be learned from before they are lost.

It is sometimes claimed that the needs of the current generation of eighty somethings should not be pressing concerns for technologists or policy makers to address. They will, after all, be dead in the next couple of decades and the next group of eighty somethings will be much more at home with digital technologies. The current rate of technological development makes this unlikely. While the eighty somethings of 2031 may be at home with chip and pins, by that time bank security may involve a nano-technology that will require users to stick their hand in a bucket of goo (or something equally unfamiliar and bewildering). The point here is an old one; improvements for minority groups are often improvements for the majority as well. You don't have to be eighty something to dislike telephone banking and online password systems, or to find it difficult to keep track of your finances. The needs of the few are also sometimes the needs of the many.

\section{ACKNOWLEDGEMENTS}

This research presented in this paper was performed as part of the New Approaches to Banking for the Older Old project, funded by Research Councils UK, Digital Economy Programme.

\section{REFERENCES}

Adams, A. and Sasse, M. A. (1999) Users are not the enemy: Why users compromise security mechanisms and how to take remedial measures. Communications of the ACM, 42, (12), 40-46.

Bank of England. (2011) What is the Bank's promise to pay?

http://www.bankofengland.co.uk/banknotes/about/f aqs.htm (18 January 2011)

Bauman, Z. (2000) Liquid Modernity. Polity, Cambridge. 
Barclays Bank. (2011) Terms and conditions for personal customers.

http://www.barclays.co.uk/Currentaccounts/Keepitsi mple/BarclaysBankAccount/P1242557963758 (18 January 2011)

BBC. (2010) Post office closures cut community ties, says watchdog.

http://news.bbc.co.uk/1/hi/wales/8496614.stm (14 January 2011)

Bell, J. (2010) Clifton OAP is conned of life savings. http://www.yorkpress.co.uk/news/8414440.OAP_is conned_of_life_savings/ (17 January 2010) Charmaz, K. (2006) Constructing grounded theory. Sage, London.

Collerton, J., Davies, K., Jagger, C., Kingston, A., Bond, J., Eccles, M. P., Leech, W., Robinson, L. A., Martin-Ruiz, C., von Zglinicki, T., James, O. F. W. and Kirkwood, T. B. L. 2009. Health and disease in 85 year olds: Baseline findings from the newcastle 85+ cohort study. British Medical Journal, 339, (b4904), 1-11.

Coventry, L., De Angeli, A. and Johnson, G. (2003) Usability and biometric verification at the atm interface. $\mathrm{CHI}$ '03, Fort Launderdale, Florida, 5-10 April. 153-160.

Department of Business, Information and Skills. (2010) Securing the post office network in the digital age. Department for Business, Innovation and Skills, London.

Dini, E. and Goldring, S. (2008) Estimating the changing population of the 'oldest old', ONS population trends, 132, 7-16

Dourish, P., Grinter, R. E., Delgado de la Flor, J. and Joseph, M. (2004) Security in the wild: User strategies for managing security as an everyday, practical problem. Personal and Ubiquitous Computing, 8, (6) 391-401.

Dunphy, P., Heiner, A. P. and Asokan, N. (2010) A closer look at recognition-based graphical passwords on mobile devices. SOUPS '10, Redmond, WA, 14-16 July.

Ferguson, N. (2008) The ascent of money. Penguin, New York.
Financial Services Authority. (2009) Fourth annual report on progress towards the shared goal for banking. Financial Services Authority, London.

Gibson, J. (1986) The Ecological Approach to Visual Perception. Lawrence Erlbaum, London.

Glaser, B. G. and Strauss, A. L. (1967) Discovery of grounded theory: Strategies for qualitative research. Aldine Publishing Company, Chicago.

Grinter, R. E. and Palen, L. (2002) Instant messaging in teen life. CSCW '02, New Orleans, Louisiana, 16-20 November, 21-30.

Help the Aged. (2006) Crime and fear of crime: Help the aged policy statement 2006. http://policy.helptheaged.org.uk/NR/rdonlyres/A3E3 7DC2-D0AD-4D15-BB57-ED9BE32130CC/0/

crime_and_fear_of_crime_april06.pdf (25 January 2011)

HM Treasury. (2007) Financial Inclusion: An Action Plan for 2008-11. HM Treasury, London.

Joyce, J. (1960) Ulysses. The Bodley Head, London.

Kawakami, K. (1997) 99 more un-useless Japanese inventions: The Japanese art of chindogu. Harper Collins, London.

Singh, S., Cabraal, A., Demosthenous, C., Astbrink, G. and Furlong, M. (2007) Password sharing: Implications for security design based on social practice. CHI 2007, San Jose, CA, 28 April 3 May, 895-904.

United Nations. (2002) World population ageing: 1950-2050.

http://www.un.org/esa/population/publications/world ageing19502050 (13 January 2011)

Wells, J. (2008) An inclusive approach to financial products. Age Concern UK, London.

Zopa. (2005) Zopa UK loans. http://uk.zopa.com/ZopaWeb (10 January 2011)

Zurko, M. E. and Simon, R. T. (1996) User-centred security. 1996 ACM New Security Paradigm Workshop. Lake Arrowhead, CA, 17-20 September, 27-33. 